14. Кримінальний процесуальний кодекс України. Науково-практичний коментар : у 2 т. Т. 1 / О.М. Бандурка, С.М. Блажівський, С.П. Бурдоль та ін. ; за заг. ред. В.Я. Тація, В.П. Пшонки, А.В. Портнова. Харків : Право, 2012. 768 с.

15. Малярова В.О. Належність та допустимість доказів у кримінальному провадженні. Науковий вісник Ужгородського національного університету. Серія ПРАВО. 2016. Випуск 38. Том 2. С. 119-121.

16. Кипнис Н.М. Допустимость доказательств в уголовном судопроизводстве / Отв. ред. П.А. Лупинская. Москва : Юристь, 1995. 128 с.

17. Кримінальний процесуальний кодекс України. Науково-практичний коментар: у 2 т. Т. 1 / О.М. Бандурка, Є.М. Блажівський, Є.П. Бурдоль та інші ; за заг. ред. В.Я. Тація, В.П. Пшонки, А.В. Портнова. Харків : Право, 2012. 768 с.

18. Павлишин А. Окремі питання допустимості доказів за Кримінальним процесуальним кодексом України 2012 року. Вісник Львівського університету. Серія юридична. 2014. Випуск 59. C. $356-364$.

19. Сівочек С.М. Оцінка джерел доказів у кримінальному процесі: дис. ... кандидата юрид. наук : 12.00.09 / Сівочек Сергій Миколайович. Киев, 2003. 215 с.

20. Острійчук О.П. Поняття та система процесуальних джерел доказів у контексті реформування процеу доказування в кримінальному процесі. Форум права. 2013. № 1. С. 745-750.

21. Про внесення змін до деяких законодавчих актів України щодо спрощення досудового розслідування окремих категорій кримінальних правопорушень: Закон України № 2617-VIII від 22 листопада 2018 року https://zakon.rada.gov.ua/laws/show/2617-19.

22. Сачко О.В. Забезпечення верховенства права при застосуванні особливих форм, порядків та режимів кримінального провадження : дис. ... доктора юрид. наук: спец. 12.00.09. Дніпро. 2019. $488 \mathrm{c}$.

УДК 343.137: 341.44

DOI https://doi.org/10.32844/2618-1258.2019.6.54

БОРТНИЦЬКА В.В.

\title{
МІЖНАРОДНА РЕГЛАМЕНТАЦІЯ ЗАСТОСУВАННЯ СПРОЩЕНОГО ПОРЯДКУ ВИДАЧІ ОСІБ
}

Стаття присвячена аналізу міжнародної регламентації застосування спрощеного порядку видачі осіб. Здійснено класифікацію умов видачі особи. Визначено обов'язкові умови видачі, умови, наявність яких перешкоджає здійсненню видачі осіб, та умови, наявність яких дає право відмовити у видачі особи або погодитися на видачу особи залежно від обставин. Проаналізовано КПК України на предмет відповідності змісту Європейської конвенції про видачу правопорушників та додаткових протоколів до неї та визначено коло питань, які не знайшли відображення в КПК України. З'ясовано, що суб'єктами, які приймають участь у розгляді питання щодо тимчасового арешту або розгляду згоди про спрощений порядок видачі особи, є особа, яка підлягає видачі, iї захисник, прокурор, який звертається до слідчого судді з клопотанням про застосування тимчасового арешту або який приймає участь у розгляді питання щодо затвердження згоди особи на видачу, та слідчий суддя, який затверджує таку згоду. У разі, якщо запит про видачу правопорушника стосується декількох окремих правопорушень, кожне з яких за законами запитуючої Сторони і запитуваної Сторони карається позбавленням волі, але якщо деякі з них не задовольняють умови стосовно тривалості терміну покарання, яке може бути призначене, то запитувана Сторона має право здійснити видачу особи, якщо хоча б одне із правопорушень відповідає умовам стосовно тривалості термі-

(C) БОРТНИЦЬКА В.В. - здобувач (Харківський національний університет внутрішніх справ) 
ну покарання. Наголошено на доцільності обмежити строк виконання обов'язку направлення регіональною прокуратурою копії ухвали слідчого судді, постановленої за результатами розгляду питання щодо затвердження згоди особи на ії̈ видачу (екстрадицію), разом із копією письмової заяви особи про згоду на ії видачу (екстрадицію) до уповноваженого (центрального) органу України невідкладно, але не пізніше 24 годин з моменту надходження копії ухвали. Зроблено висновки, що умови видачі особи можна поділити на: обов'язкові, тобто ті, наявність яких передбачає виконання державою зобов'язання щодо видачі особи, та умови, наявність яких перешкоджає здійсненню видачі осіб, умови, наявність яких дає право відмовити у видачі особи або погодитися на видачу особи залежно від обставин.

Ключові слова: спрощений порядок видачі осіб, конвенція про видачу, умови видачі особи, застереження, ратифікація.

The article is devoted to the analysis of the international regulation of application of the simplified procedure for extradition of persons. The classification of the conditions of extradition was made. Required conditions of extradition are determined, the conditions which prevent the extradition of persons and the conditions which entitle them to refuse to extradite a person or to consent to extradition, as the case may be. The CPC of Ukraine has been analyzed for compliance with the content of the European Convention on the Issue of Offenders and Additional Protocols thereto, and identified a number of issues that were not reflected in the CPC of Ukraine. It is found that the subjects involved in the consideration of the temporary arrest or the consideration of the consent to the simplified order of extradition are the person to be extradited, his defense attorney, the prosecutor, who asks the investigating judge to apply for the temporary arrest, or who is involved in considering whether to grant the person's consent to extradition, and the investigating judge who approves such consent. If the request for extradition concerns several separate offenses, each of which is punishable by imprisonment under the laws of the requesting Party and the requested Party, but if some of them do not satisfy the conditions for the length of sentence that may be imposed, the requested Party is entitled extradite a person if at least one of the offenses meets the conditions regarding the length of the sentence. It is emphasized that it is expedient to limit the term of fulfillment of the obligation to send to the Regional Prosecutor's Office a copy of the decision of the investigating judge, issued after the consideration of the issue of approval of the person's consent to his extradition, together with a copy of the written statement of the person's consent to his extradition central body of Ukraine immediately, but not later than 24 hours after the receipt of the copy of the order. It is concluded that the conditions of extradition can be divided into: obligatory, that is, those whose existence implies the fulfillment of a state obligation to extradite a person, and conditions that impede the extradition of persons, the conditions which entitle him to refuse extradition person, or agree to extradition as the case may be.

Key words: simplified procedure for extradition of persons, extradition convention, conditions for extradition of person, reservation, ratification.

Вступ. Сьогодні розвиток кримінального процесуального законодавства та об'єднання зусиль між державами сприяє розвитку все нових форм та механізмів, які забезпечують виконання принципу невідворотності покарання. Одним із таких механізмів $є$ спрощений порядок видачі осіб, який є достатньо новим для законодавства України. Зазначене зумовлює не лише недостатню кількість спеціальної літератури з цього питання, а й відсутність сформованої практики його застосування. Під час застосування багатосторонніх міжнародних договорів України їх положення діють з урахуванням заяв і застережень України, висловлених під час ратифікації чи приєднання, та заяв і застережень відповідної іноземної держави. Тому питання міжнародної регламентації застосування спрощеного порядку видачі осіб необхідно розглядати з урахуванням таких застережень.

Аналіз останніх досліджень і публікацій. Питання міжнародної регламентації застосування спрощеного порядку видачі осіб деякою мірою досліджувалось в роботах Ю.П. Аленіна, О.П. Бичківського, О.В. Буткевича, Ю.Г. Васильева, С.М. Вихриста, С.В. Ківалова, С.Ф. Кравчу- 
ка, О. Мережка, В.В. Мицика, С.С. Нестеренка, М.П. Свистуленка, О.В. Сурілова, В. Тертишника, А. Штиглица та інших. Однак такі дослідження були здійснені до запровадження спрощеного порядку видачі осіб і не враховують його положень.

Постановказавдання. Зогляду назазначене метою нашої статтіє здійснення порівняльного аналізу міжнародної регламентації спрощеного порядку видачі із законодавством України, здійснення класифікації умов видачі осіб, закріплених міжнародними договорами, та визначення положень міжнародного законодавства, які не достатньою мірою відображені в законодавстві України.

Результати дослідження. Процедура видачі особи у спрощеному порядку визначена у ст. 16 Свропейської Конвенції про видачу правопорушників 1957 року із доповненнями, внесеними Третім додатковим протоколом до Європейської конвенції про видачу правопорушників 2010 року, під час ратифікації яких Україна заявляла застереження.

Процедура видачі особи у спрощеному порядку здійснюється на підставі запиту про тимчасовий арешт. Тимчасовий арешт займає, умовно кажучи, серединне положення між затриманням особи та вирішенням питання про застосування до неї екстрадиційного арешту. Так, у разі затримання особи, яка вчинила кримінальне правопорушення за межами України, протягом 72 годин повинно бути вирішено питання про звільнення особи або застосування до неї запобіжного заходу у вигляді тимчасового арешту [1].

У запиті про тимчасовий арешт має міститися повідомлення про намір надіслати запит про видачу правопорушника, а також такі відомості: а) ідентифікаційні дані розшукуваної особи, включаючи інформацію щодо іiі громадянства / громадянств, якщо така інформація є наявною; b) орган, який запитує арешт; c) існування ордера на арешт чи іншого документа, який має таку саму юридичну силу, або рішення суду, що підлягає виконанню, а також підтвердження того, що особа розшукується відповідно до статті 1 Конвенції; d) характер і юридичну кваліфікацію правопорушення, включаючи максимальне покарання або покарання, призначене в остаточному рішенні, разом з інформацією про те, чи була будь-яка частина такого рішення вже виконаною; е) інформацію щодо строків давності та зупинення їх перебігу; f) опис обставин, за яких правопорушення було вчинено, включаючи час, місце та ступінь участі розшукуваної особи; g) наскільки це можливо - наслідки правопорушення; h) у випадках, коли видача запитується з метою виконання остаточного рішення, - інформацію про те, чи було рішення ухвалено in absentia. Аналіз ч. 6 ст. 588 КПК України свідчить, що вимоги до запиту про видачу співпадають із вимогами, представленими в Конвенції.

Процедура видачі особи у спрощеному порядку можлива лише за наявності умов, визначених міжнародними договорами.

Аналіз Конвенції про передачу засуджених осіб, 1983 р. та Європейської конвенції про видачу правопорушників від 13 грудня 1957 року свідчить, що умови застосування спрощеного порядку видачі диференціюються за ступенем обов'язковості на такі, що передбачають обов'язкове здійснення видачі особи, забороняють видачу особи та дозволяють видачу на розсуд держави, яка видає.

Аналіз міжнародних договорів свідчить, що обов'язковими умовами видачі осіб (тобто тими, наявність яких передбачає виконання державною зобов'язання щодо видачі особи) є: вчинення правопорушень, які караються за законами запитуючої Сторони та запитуваної Сторони позбавленням волі або згідно з постановою про утримання під вартою на максимальний термін не менше одного року чи більш суворим покаранням (ч. 1 ст. 2) [2]. Україна ратифікувала Європейську конвенцію про видачу правопорушників із застереженням до пункту 1 статті 2 , відповідно до якого Україна здійснюватиме видачу лише осіб, які вчинили злочини, що караються позбавленням волі на максимальний строк не менше одного року або більш суворим покаранням [3].

Видача здійснюється, відповідно до положень цієї Конвенції, за правопорушення, пов'язані з податками, зборами, митом та валютою, за умови, якщо Договірні Сторони ухвалили таке рішення стосовно будь-якого такого правопорушення або категорії правопорушень (ст. 5) [2]. При прийнятті рішення на цій підставі уповноважений (центральний) орган України зобов'язаний переконатися в наявності додаткового договору з запитуючою стороною щодо фінансових правопорушень.

Видача не здійснюється у разі існування таких обставин (умови, наявність яких перешкоджає здійсненню видачі осіб): якщо термін призначеного покарання складає не менше чотирьох місяців у разі, якщо особа визнається винною і вирок про ув'язнення або постанова про утримання під вартою проголошується на території запитуючої Сторони (ч. 2 ст. 2) [2]; якщо правопорушення за законодавством Запитуваної Сторони вважається вчиненим повністю або частково 
на іiї території або в місці, яке розглядається як ії територія, центральний уповноважений орган відмовляє у видачі (ч. 1 ст. 7) [2]; якщо особа, видача якої запитується, за станом здоров'я не може бути видана без шкоди ії здоров'ю. Так, відповідно до Закону України Про ратифікацію Європейської конвенції про видачу правопорушників 1957 року, Додаткового протоколу 1975 року та Другого додаткового протоколу 1978 року до Конвенції про видачу правопорушників Україна залишає за собою право не здійснювати видачу, якщо особа, видача якої запитується, за станом здоров'я не може бути видана без шкоди іiі здоров'ю [2]; якщо правопорушення, у зв'язку 3 яким запитується особа, розглядається запитуваною Стороною як політичне правопорушення або правопорушення, пов'язане 3 політичним правопорушенням, видача особи не здійснюється (ч. 1 ст. 3) [2]; якщо запитувана Сторона має достатньо підстав вважати, що запит про видачу правопорушника за вчинення звичайного кримінального правопорушення був зроблений з метою переслідування або покарання особи на підставі ііі раси, релігії, національної приналежності чи політичних переконань або що становище такої особи може бути зашкоджене з будь-якої з цих причин видача особи не здійснюється (ч. 1 ст. 3) [2]; якщо запитувана особа $є$ громадянином запитуваної Сторони. Відповідно до Європейської конвенції про видачу правопорушників 1957 року Договірна Сторона має право відмовити у видачі своїх громадян (п. а ч. 1 ст. 6) [2].

Однак відповідно до Закону України Про ратифікацію Європейської конвенції про видачу правопорушників 1957 року, Додаткового протоколу 1975 року та Другого додаткового протоколу 1978 року до Конвенції видачу правопорушників Україна не видаватиме іншій державі громадян України [3]. Положення п. а ч. 1 ст. 6 Європейської конвенції про видачу правопорушників 1957 року мають декларативний характер, разом з тим застереження, зроблене Україною, висловлене у вигляді імперативної норми. 3 огляду на це видача громадян України іншій державі не здійснюється.

Відповідно до Додаткового протоколу до Європейської конвенції про видачу правопорушників від 15 жовтня 1975 року визначено, що видача громадян України не здійснюється.

Як вже зазначалося, видача особи не здійснюється, якщо правопорушення, у зв'язку з яким запитується особа, розглядається запитуваною Стороною як політичне правопорушення або правопорушення, пов'язане з політичним правопорушенням (ч. 1 ст. 3) [2]. Відповідно до Додаткового протоколу до Європейської конвенції про видачу правопорушників від 15 жовтня 1975 року визначено коло правопорушень, які не є політичними. Разом з тим відповідно до Закону України Про ратифікацію Європейської конвенції про видачу правопорушників 1957 року, Додаткового протоколу 1975 року та Другого додаткового протоколу 1978 року до Конвенції про видачу правопорушників Україна заявила, що вона не приймає главу І Додаткового протоколу 1975 року і залишає за собою право вирішувати відповідно до неї в кожній окремій справі задовольняти чи не задовольняти запит про видачу правопорушника [3]. Однак сьогодні в законодавстві України відсутній механізм та критерії вирішення питання про приналежність правопорушення до політичного або пов'язаного з політичним правопорушенням.

Якщо закінчилися строки давності переслідування чи покарання особи, видача якої запитується, відповідно до законодавства запитуючої Сторони (ст. 1, якою замінено ст. 10 Конвенції) видача особи не здійснюється.

3 огляду на зазначене уповноважений (центральний) орган України, виявивши одну із зазначених обставин, зобов'язаний відмовити у видачі особи у спрощеному порядку навіть за наявності згоди особи на таку видачу.

Відповідно до Європейської конвенції про видачу правопорушників 1957 року Договірна Сторона має право відмовити у видачі особи або погодитися на видачу особи залежно від обставин. До таких обставин належать такі: якщо правопорушення, за яке вимагається видача, було вчинене за межами території запитуючої Сторони, у видачі може бути відмовлено (ч. 2 ст. 7) [2]. Однак така Відмова у видачі можлива, якщо законодавство запитуваної Сторони не передбачає переслідування за таку саму категорію правопорушень у разі їх вчинення за межами території останньої Сторони або не передбачає видачі за правопорушення, у зв'язку з яким вимагається видача (ч. 2 ст. 7) [2]; якщо правопорушення, за яке вимагається видача, карається смертною карою за законодавством запитуючої Сторони і якщо законодавство запитуваної Сторони не передбачає смертної кари за таке саме правопорушення або вона зазвичай не виконується, у видачі може бути відмовлено, якщо запитуюча Сторона не надасть запитуваній Стороні достатніх гарантій того, що смертний вирок не буде звернутий до виконання.

Видача за правопорушення, які передбачені військовим правом і які не $\epsilon$ правопорушеннями за звичайним кримінальним правом, із сфери застосування цієї Конвенції вилучаються. Однак 
відповідно до Закону України «Про ратифікацію Європейської конвенції про видачу правопорушників» 1957 року, Додаткового протоколу 1975 року та Другого додаткового протоколу 1978 року до Конвенції видачу правопорушників за вчинення загальнокримінальних правопорушень, що також $\epsilon$ військовими правопорушеннями, може бути здійснено Україною лише за умови, якщо особу, видача якої запитується, не буде піддано кримінальному переслідуванню за військовим правом або законом [3].

Якщо запит про видачу правопорушника стосується декількох окремих правопорушень, кожне з яких за законами запитуючої Сторони і запитуваної Сторони карається позбавленням волі, але якщо деякі з них не задовольняють умови стосовно тривалості терміну покарання, яке може бути призначене, то запитувана Сторона має право здійснити видачу особи, якщо хоча б одне із правопорушень відповідає умовам стосовно тривалості терміну покарання (ч. 3 ст. 2) [2].

Відповідно до ст. 3 Конвенції про передачу засуджених осіб 1983 р. засуджену особу може бути передано за цією Конвенцією тільки за таких умов: а) якщо ця особа $є$ громадянином держави виконання вироку; b) якщо рішення є остаточним; с) якщо на час отримання запиту про передачу засуджена особа має відбувати покарання впродовж якнайменш шести місяців, або якщо їй винесено вирок до ув'язнення на невизначений строк; d) якщо на передачу згодна засуджена особа, або коли з врахуванням іiї віку або фізичного чи психічного стану одна із двох держав вважає це за необхідне, - законний представник засудженої особи; е) якщо дія або бездіяльність, на підставі якої було винесено вирок, $є$ кримінальним злочином згідно із законодавством держави виконання вироку або була б кримінальним злочином у разі вчинення на її території; f) якщо держава винесення вироку і держава виконання вироку згодні на передачу засудженої особи.

Отже, умови видачі особи можна поділити на: обов'язкові, тобто ті, наявність яких передбачає виконання державною зобов'язання щодо видачі особи, та умови, наявність яких перешкоджає здійсненню видачі осіб, умови, наявність яких дає право відмовити у видачі особи або погодитися на видачу особи в залежно від обставин.

Відповідно до п. 3 ст. 2 Третього додаткового протоколу до Європейської конвенції про видачу правопорушників 2010 року зазначено, що у випадках, коли запитувана Сторона отримала запит про видачу відповідно до статті 12 Конвенції, цей Протокол застосовується mutatis mutandis [4]. 3 огляду на зазначене спрощений порядок видачі осіб можливий і у разі надходження запиту про видачу без проведення екстрадиційної перевірки.

У Третьому додатковому протоколі до Європейської конвенції про видачу правопорушників 2010 року передбачено обов'язок інформування особи про можливість застосування спрощеної процедури видачі відповідно до Протоколу (ст. 3) [4]. Зазначена процедура знайшла відображення і в КПК України - відповідно до ч. 4 ст. 583 КПК України до клопотання про застосування тимчасового арешту додається протокол затримання особи з відміткою про роз'яснення особі iii права надати згоду на видачу (екстрадицію) для застосування процедури видачі (екстрадиціі) у спрощеному порядку, а також права на відмову від застосування спеціального правила щодо меж кримінальної відповідальності у разі надання згоди на іії видачу (екстрадицію).

У ст. 4 Третього додаткового протоколу до Європейської конвенції про видачу правопорушників 2010 року зазначено, що згода розшукуваної особи на видачу та у відповідному випадку іiі явно висловлена відмова від права застосування спеціального правила повинні бути надані компетентному судовому органу запитуваної Сторони відповідно до законодавства такої Сторони, що відображено у п. 4 ч. 6 ст. 583 КПК України, відповідно до якої копія ухвали слідчого судді, постановленої за результатами розгляду питання щодо затвердження згоди особи на іiї видачу (екстрадицію), невідкладно направляється уповноваженому (центральному) органу України через відповідну регіональну прокуратуру разом із копією письмової заяви особи про згоду на іiї видачу (екстрадицію). Зазначена стаття має імперативний характер, однак у ній не визначено суб'єкта, на якого б покладався обов'язок реалізації зазначеної норми. Імперативні норми безпосередньо визначають поведінку суб'єктів суспільних відносин та не можуть бути змінені за власним розсудом таких осіб $[4$, с. $47 ; 5$, с. 126$]$. 3 огляду на зазначене норма п. 4 ч. 6 ст. 583 КПК України дійсно визначає поведінку, однак не містить посилання на суб'єкта, яким має бути реалізована. 3 огляду на це можна зробити висновок про те, що норма сформульована не коректно і потребує доопрацювання. Проаналізуємо зазначену норму з погляду суб'єктів, яким вона може бути адресована і спробуємо сформулювати авторське бачення такої норми. Так, суб'єктами, які приймають участь у розгляді питання щодо тимчасового арешту або розгляду згоди про спрощений порядок видачі особи, є особа, яка підлягає видачі, іiі захисник, прокурор, який звертається до слідчого судді з клопотанням про застосування тимчасового арешту або який 
приймає участь у розгляді питання щодо затвердження згоди особи на видачу, та слідчий суддя, який затверджує таку згоду.

На особу, яка підлягає видачі, чи іiї захисника не може бути покладено такого обов'язку, оскільки це суперечить концепції КПК України. Такий обов'язок може бути покладено на прокурора, який звертається до слідчого судді з клопотанням про застосування тимчасового арешту, приймає участь у його розгляді, а також приймає участь у розгляді питання щодо затвердження згоди особи на видачу. Разом з тим участь прокурора під час затвердження згоди особи на видачу $€$ необов'язковою, тому у випадках, коли це здійснюється без його участі, покладення обов'язку, про який йдеться, $є$ нераціональним і не результативним рішенням. Крім того, відповідно до ч. 5 ст. 588 КПК України про затвердження слідчим суддею згоди особи на її видачу (екстрадицію) або відмову особи від застосування спеціального правила щодо меж кримінальної відповідальності уповноважений (центральний) орган України невідкладно інформує компетентний орган іноземної держави, яка розшукує особу для притягнення до кримінальної відповідальності. Тобто обов'язок невідкладного інформування компетентного органу іноземної держави, яка розшукує особу для притягнення до кримінальної відповідальності, покладено на Генеральну прокуратуру та Міністерство юстиції України.

Щодо слідчого судді, то відповідно до п. 18 ч. 1 ст. 3 КПК України до його повноважень належить здійснення судового контролю за дотриманням прав, свобод та інтересів осіб у кримінальному провадженні. До повноважень слідчого судді не належить забезпечення виконання постановлених рішень чи контроль за їх виконанням. Тому, на нашу думку, на слідчого суддю, з одного боку, не зовсім правильно покладати обовязок надсилання копії ухвали, постановленої за результатами розгляду питання щодо затвердження згоди особи на ії видачу (екстрадицію). Хоча, 3 іншого боку, попри те, що на слідчого суддю не покладено такого обов'язку, на практиці все ж таки слідчі судді вживають заходів для забезпечення виконання ухвали. Зазначене стосується не лише ухвали про затвердження згоди особи на спрощений порядок видачі особи з України, а, наприклад, під час розгляду скарг на рішення, дії чи бездіяльність слідчого, прокурора на стадії досудового розслідування. Ухвалені рішення слідчі судді направляють на виконання слідчим i прокурорам. 3 огляду на зазначене, а також з урахуванням того, що участь прокурора під час розгляду питання щодо затвердження згоди особи не $\epsilon$ обов'язковою, вбачається за доцільне покласти обов'язок направлення копії ухвали, постановленої за результатами розгляду питання щодо затвердження згоди особи на її видачу (екстрадицію), у відповідну регіональну прокуратуру разом із копією письмової заяви особи про згоду на їі видачу (екстрадицію). Регіональна прокуратура невідкладно направляє копію ухвали слідчого судді, постановленої за результатами розгляду питання щодо затвердження згоди особи на її видачу (екстрадицію), разом із копією письмової заяви особи про згоду на ії видачу (екстрадицію) до уповноваженого (центрального) органу України. Крім того, на нашу думку, термін «невідкладно» досить абстрактно визначає строки направлення копії ухвали. На нашу думку, доцільно обмежити строк виконання обов'язку направлення регіональною прокуратурою копії ухвали слідчого судді, постановленої за результатами розгляду питання щодо затвердження згоди особи на ії видачу (екстрадицію), разом із копією письмової заяви особи про згоду на їі видачу (екстрадицію) до уповноваженого (центрального) органу України невідкладно, але не пізніше 24 годин з моменту надходження копії ухвали.

Висновки. Умови видачі особи можна поділити на: обов'язкові, тобто ті, наявність яких передбачає виконання державною зобов'язання щодо видачі особи; умови, наявність яких перешкоджає здійсненню видачі осіб; умови, наявність яких дає право відмовити у видачі особи або погодитися на видачу особи залежно від обставин.

\section{Список використаних джерел:}

1. Фоміна Т.Г. Тимчасовий арешт як спеціальний вид тримання під вартою: підстави. Часопис Київського університету права. 2017. № 4. С. 230-234.

2. Європейська конвенція про видачу правопорушників від 13 грудня 1957 року. URL: https://zakon.rada.gov.ua/laws/show/995_033.

3. Про ратифікацію Європейської конвенції про видачу правопорушників, 1957 рік, Додаткового протоколу 1975 року та Другого додаткового протоколу 1978 року до Конвенції. Закон України від 16 січня 1998 року. URL: https://zakon.rada.gov.ua/laws/show/43/98-\%D0\%B2\%D1\%80.

4. Погрібний С.О. Імперативні та диспозитивні норми та їх роль в регулюванні цивільних відносин. Університетські наукові записки. 2010. № 2(34). С. 46-54.

5. Рабіновіч П.М. Основи загальної теорії права та держави. Навчальний посібник. Київ. 2001. $176 \mathrm{c}$. 